\title{
The Socio-Economic Impacts of Aged-Dam Removal: A Review
}

\author{
Duminda Perera ${ }^{1,2,3 *}$, Taylor North ${ }^{2}$ \\ ${ }^{1}$ United Nations University Institute for Water, Environment, and Health, Hamilton, Canada \\ ${ }^{2}$ McMaster University, Hamilton, Canada \\ ${ }^{3}$ University of Ottawa, Ottawa, Canada \\ Email: *duminda.perera@unu.edu
}

How to cite this paper: Perera, D., \& North, T. (2021). The Socio-Economic Impacts of Aged-Dam Removal: A Review. Journal of Geoscience and Environment Protection, 9, 62-78.

https://doi.org/10.4236/gep.2021.910005

Received: September 1, 2021

Accepted: October 19, 2021

Published: October 22, 2021

Copyright (c) 2021 by author(s) and Scientific Research Publishing Inc. This work is licensed under the Creative Commons Attribution International License (CC BY 4.0).

http://creativecommons.org/licenses/by/4.0/

\begin{abstract}
Water storage dams worldwide are ageing, and many will reach the end of their designed lifespan by the middle of the 21 st century. Some of these dams will likely need to be removed. While dam construction impacts have been widely discussed, dam removal impacts on society and the economy need to be synthesized and considered in the ageing dams' decision-making process. This paper summarizes dam removal impacts on the local economy and industry, culture, history and heritage, property value, recreation, aesthetics, and disaster avoidance from identified studies worldwide. It demonstrates that these impacts may vary depending on geography and between developed and developing countries. It concludes that dam removal should consider the cost, environmental, and the socio-economic impacts while including all stakeholders who could be positively and negatively impacted by dam removal.
\end{abstract}

\section{Keywords}

Dam Ageing, Dam Removal, Large Dams, Social Impacts, Economic Impacts

\section{Introduction}

Water storage infrastructure, particularly large dams, has traditionally been used to regulate river flows globally, benefiting countries by fulfilling water and energy needs. By 2020, the global large dam count was over 58,000 (>15 m height; or $5-15 \mathrm{~m}$ height and impounding $>3$ million $\mathrm{m}^{3}$ of storage as defined by the International Commission on Large Dams-ICOLD-

https://www.icold-cigb.org/GB/icold/icold.asp). Cumulatively, dams store approximately $16 \%$ of global surface water resources (Hanasaki et al., 2006). Around $93 \%$ of the world's large dams are built in 25 countries, with China and 
the USA leading with the greatest number of large dams $(23,841 \& 9263$, respectively). By continent, Asia has the majority ( $55 \%)$ of the large dams globally, while Africa has the fewest ( 2000; ICOLD WRD, 2020).

The main dam functions are irrigation, hydropower, water supply, and flood control, while other functions include recreation, navigation, and fish farming (ICOLD WRD, 2020). Irrigated agriculture ensured largely by dams, contributes about $40 \%$ of world agricultural production (Shah \& Kumar, 2008), while hydropower dams generate around $20 \%$ of global electricity production (IHA, 2020). Dams store large volumes of water during extreme rainfall events, reducing the likelihood of downstream flood disasters (Berga, 2009). Additionally, most of the world's urban, agricultural, and industrial regions' water security is sustained by these large storages (Vörösmarty et al., 2010).

Building of large dams was upsurged in the mid-20th century, and its peak was in 1960-1980s, and declined afterward (Perera et al., 2021) due to a range of factors, including environmental and social costs, lack of transparency, low stakeholder participation, and reduced finances and investments (Grigg, 2019). Like any infrastructure, large dams are constructed with a design life, and as they age, they become more expensive to repair and maintain and increasingly vulnerable to failure. Ageing is understood to be the gradual deterioration beyond the initial five years of operation (Zamarrón-Mieza et al., 2017). In general, dams constructed between 1930-1970 have an average design life ranging from 50 to 100 years (Mahmood, 1987; Ho et al., 2017). Consequently, many large dams worldwide have reached or are approaching the 50 years mark, which may be seen as the lower boundary of their design lifespan. Regular inspection and repair with a sound management plan can significantly extend a dam's life span, yet many ageing dams will likely be considered for re-operation or complete removal. Dam removal, and particularly large dam removal, is not yet a common practice nor an easy process. There are many factors, including the cost of repair, cost of removal, socio-economic impacts, public safety, environmental impacts, and government policies for water, energy, and food production, amongst others, that need to be considered to make informed decisions on dam removal. While the cost of removal, loss of dam function, and environmental impacts are key considerations in the removal process, there is a range of important socio-economic impacts that are important to distill from global emerging practices and should be considered as well. This paper aims to identify such socio-economic impacts of dam removal as reported in the global literature.

\section{Dam Ageing and Removal: A Global Snapshot}

Dam ageing is gradually appearing as a global development challenge experienced by many countries. Perera et al. (2021) carried out the first global synthesis of ageing water storage infrastructure, illustrating the magnitude of the problem by major geographical region, country, and dam function, quantifying emerging trends of dam removal, and identifying the key considerations for decision-making on 
aged-dam removal. Figure 1 provides a snapshot of the current knowledge of dam age by major region and dam function.

In North America and Asia, 16,000 large dams are between 50 and 100 years old, and over 2000 dams were constructed over a century ago. In Europe, 10\% of large dams are over 100 years old, while in the United Kingdom, large dams' average age is greater than 100 years (Perera et al., 2021). In the USA, over $85 \%$ of dams exceed their design life expectancy (FEMA, 1999). Dam ageing poses a threat poses a threat to public safety and has potentially dramatic impacts on both the economy and the environment.

The risks linked with ageing large dams are extreme and can result in loss of life, property, and livelihoods. For example, in March 2009 the Situ Gintung Dam failed in Indonesia's Tangerang District, killing over 100 individuals. Built-in 1933, little maintenance had been done for 76 years (USBR, 2015). Unfortunately, this is not an isolated case and ageing dam failures threaten lives across the globe (e.g., Ivanovo Dam, 2012; Kantale Dam, 1986; Kelly Barnes Dam, 1977; Table 1). Over 30,000 dams in China are ageing and at high risk of failure (Yang et al., 2011), while in the USA approximately $15 \%$ of dams are considered a high hazard (Ho et al., 2017). By 2050, the predicted world total population will be nearly 10 billion (UN Water, 2019). The majority of the population will reside downstream of large dams (Ferre et al., 2014), primarily constructed in the 20th century or the early 21 st century. Therefore, informed decision-making regarding ageing dams will be paramount to protect growing downstream communities. The impacts of dam ageing can be local, national, or international (e.g., dams in transboundary rivers). The unique characteristics of each dam (location, age, function, capacity, etc.) make the ageing issue very diverse. Thus, the problems arising from ageing dams will manifest themselves in different ways and at different times. Additionally, other risk factors such as climate change-induced extreme events, sedimentation, environmental impacts, and security threats will lead stakeholders to decide on each dam's fate in the 21 st century.

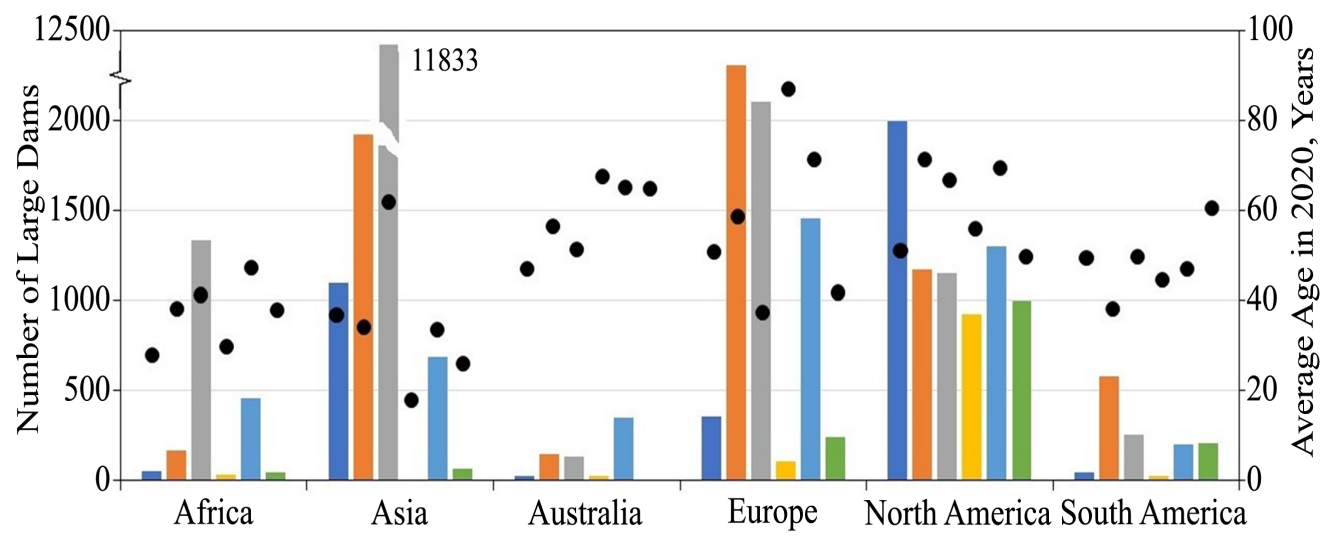

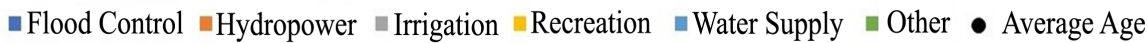

Figure 1. Average age (circles) and number of large dams (bars) in main geographic regions by their functions (graph source: Perera et al., 2021 based on ICOLD data). 
Table 1. Examples of dam failures from ageing infrastructure.

\begin{tabular}{|c|c|c|c|c|c|}
\hline Dam Name & Country & Age & $\begin{array}{l}\text { Year of } \\
\text { Failure }\end{array}$ & Fatalities & Reason for Failure \\
\hline $\begin{array}{l}\text { Brumadinho Dam } \\
\text { (Zimmermann, 2019) }\end{array}$ & Brazil & 43 & 2019 & 270 & Structural flaws \\
\hline $\begin{array}{c}\text { Panjshir Valley Dam } \\
\text { (Associated Press, 2018) }\end{array}$ & Afghanistan & $>50$ & 2018 & 10 & $\begin{array}{l}\text { Structural flaws, } \\
\text { heavy rain }\end{array}$ \\
\hline $\begin{array}{c}\text { Ivanovo Dam } \\
\text { (Cooper \& Gleeson, 2012) }\end{array}$ & Bulgaria & 75 & 2012 & 8 & $\begin{array}{l}\text { Structural flaws, } \\
\text { heavy snowmelt }\end{array}$ \\
\hline $\begin{array}{c}\text { Kantale Dam } \\
\text { (Jayathilaka \& } \\
\text { Munasinghe, 2014) }\end{array}$ & Sri Lanka & $>100$ & 1986 & 180 & $\begin{array}{l}\text { Structural flaws, } \\
\text { poor maintenance }\end{array}$ \\
\hline $\begin{array}{l}\text { Kelly Barnes Dam } \\
\text { (USBR, 2015) }\end{array}$ & USA & 78 & 1977 & 36 & $\begin{array}{c}\text { Elevated } \\
\text { reservoir levels }\end{array}$ \\
\hline
\end{tabular}

Dam managers can consider three potential solutions to manage ageing dams. The first is repair, which involves restoring dam function and safety to remain operational. Re-operationalization is another option that modifies the original dam operation to recover social and ecological benefits by implementing integrative management approaches (Watts et al., 2011). This could include targeting water releases from the reservoir to mimic the inflow rate, creating plans to minimize consumptive water losses from the reservoir, amongst other approaches, and can incorporate multiple dams (Watts et al., 2011). The third solution, dam removal, includes dismantling the dam completely and allowing free river flow. Thus far, most removals have occurred at small dams $(<5 \mathrm{~m})$ in the USA and Europe, and removals of large dams are still limited (Perera et al., 2021). Among the three available solutions, selecting the best option is case-specific and requires an in-depth decision-making process covering technical, social, and economic elements related to the dam.

In recent years, dam removal has gained attention as a potential solution to managing ageing infrastructure while also repairing the environmental integrity of riverine ecosystems. While dam repair preserves dam function, maintenance is often expensive and ongoing and can be $10-30$ times costlier than removal (Grabowski et al., 2018). Similarly, while re-operationalization has been demonstrated to improve the ecological (Bednarek \& Hart, 2005) and social (Vonk et al., 2014) impacts of dams, optimizing dam operations is complex and many dams no longer provide the benefits that once justified their development (Labadie, 2004). Alternatively, dam removal may involve the full or partial removal of dam infrastructure. Removal may be a feasible alternative if economic, social, and practical limitations prevent the dam from being renovated or its expected function is now outdated (Doyle et al., 2003). Removal allows rivers to flow freely again, benefitting migratory fish and aquatic ecosystems (Grant \& Lewis, 2015). However, dam removal can have consequences as well. Functionally, there may be a loss of services provided by the dam, such as hydropower generation, 
irrigation, or flood control, which may need to be replaced or recovered. This may not be advantageous for some countries, communities, and individuals that rely on dam services. Environmentally, sediments in the upstream reservoir can adsorb contaminants which may be released when the dam is removed (Grant, 2001). In these cases, repair or re-operationalization is likely a more suitable option to maintain safe dam functioning. Additionally, the lack of dam removal policies means that removal is not regulated (Doyle et al., 2003). Given this dichotomy, understanding the socio-economic impacts of dam removal remains a critical gap in ensuring the proper management of ageing infrastructure (Bellmore et al., 2017).

\section{Socio-Economic Impacts of Dam Removal}

\subsection{Local Economy and Industry}

Dam removal is becoming an accepted approach to mitigate the risks associated with ageing infrastructure. After dam removal, a shift in the industry is expected as the immediate environment and resources change. Dam removal affects the industries such as fisheries, agriculture, tourism, and hydropower and impacts livelihoods and employment opportunities.

Fisheries commonly contribute to regional economies across the globe, and particularly for low-income individuals, fish represents a major source of protein (Kent, 1997). Rivers are rarely dammed for fish harvesting as the only purpose; however, in some cases, the secondary importance of the fishery may exceed that of the reservoir's primary function (Fernando, 1980). In developed countries, reservoir fisheries often serve recreational needs, while in developing countries, reservoir fisheries provide a critical source of protein and employment often in rural communities (Sugunan, 1995). In addition, high yields in reservoirs are often a result of stocking programs where exotic fish species are introduced (Jackson \& Marmulla, 2001). Overall, reservoir ecosystems are repeatedly stressed due to the high levels of nutrient input and unidirectional flow and are not conducive to support fish populations. As a result, damming rivers may cause significant losses of riverine fish harvests (Jackson \& Marmulla, 2001). Therefore, dam removal may be beneficial to increase fishery yields.

In the USA, restoring rivers has significantly improved the quality and quantity of fish habitat and salmon migration which is both ecologically and economically beneficial (Witze, 2014). Mapes (2016) mentioned that during the first season after the Elwha Dam was removed in the USA, over 4000 spawning Chinook were observed. Several other studies conducted in the USA point to an increase in fish population after dam removal (e.g., Hardiman \& Allen, 2015; Allen et al., 2016). Likewise, after the removal of the Arase Dam in Japan, fishermen reported increased seaweed cultivation and shrimp harvesting and the return of sweetfish, a highly sought-after species (Ohno, 2019). In Sweden, after removing the Storsjö-Kapell dam in the Storsjö fisheries conservation area, fishermen expected to double the value of large fish and quadruple the fish stocks (Lejon et 
al., 2009). Since dam removal restores both terrestrial and aquatic ecological functioning, it is likely that river fisheries are more sustainable and will provide higher yields than reservoir fisheries. However, this may not be the case in more arid regions.

Dam removal can be beneficial or disastrous to the agricultural sector. Globally, nearly $50 \%$ of single-use dams were built to provide water for irrigation, and these dams supply water to over 1 million $\mathrm{km}^{2}$ of land (ICOLD WRD, 2020). The dependency on dams for irrigation is dictated primarily by climatic conditions. In temperate zones, agriculture can be conducted without a water management system, while in arid or semi-arid zones, agriculture without irrigation can be impossible (Schultz, 2002). Therefore, the impact of dam removal on agricultural production will be primarily influenced by the regional climate and water availability. Particularly for countries with emerging economies, dams, irrigation systems, and hydropower play a critical role in fighting against poverty (Barker, 2004). By increasing water availability in arid regions, more irrigable land will be used for food production, improving rural livelihoods (Hasnip et al., 2001). For example, in India, water availability for irrigation significantly reduces poverty in rural areas (Lipton \& Litchfield, 2003). However, although poverty is reduced downstream of dams providing irrigation, poverty may be increased in the dam's immediate vicinity (Duflo \& Pande, 2007). Therefore, in regions that rely on dams to supply water for irrigation, removal could have detrimental consequences to the surrounding community's livelihoods. The extent of these impacts likely varies with the vicinity of the dam.

In many regions, dam removal may benefit individuals who previously relied on the reservoir footprint for their livelihoods, such as pastoral communities or those who partake in subsistence farming. For example, after the Senegal River was dammed in the 1980s, over 300,000 individuals lost their traditional flood-recession farming land and practices (Adams, 2000). If the dam was removed, these individuals could reclaim their land and traditions. In Alberta, Canada, the construction of the Bighorn Dam on the North Saskatchewan River in the 1970s flooded the entire land claim of the Bighorn First Nation, which prevented hunting, guiding, and fur trapping and forced $95 \%$ of the population onto welfare (Notzke, 1994).

In addition to agriculture and fisheries, tourism is another sector that can be stimulated by dam removal in a local/regional economy. For example, after the Arase Dam removal in Japan, the village saw a boom in local job opportunities. Riverboat and rafting companies began offering tours along the river, sweetfish restaurants opened, and fishing weirs were installed as tourist attractions (Ohno, 2019). The increase in tourism and the accompanying infrastructure led to the revitalization of the Sakamoto Village (Ohno, 2019). Likewise, a cost-benefit analysis regarding the removal of dams along the Snake River, USA, demonstrated that after removal, the largest long-term increase in employment would occur because of increased tourism (Whitelaw \& Macmullan, 2002). However, these dams were never removed. 
Twenty percent of the world's electricity is generated by hydropower, the primary renewable energy source (WWAP, 2017). Although access to electricity has increased from $71 \%$ in 1990 to $87 \%$ in 2016, nearly one billion people still lack access to electricity, predominately in Africa and South Asia (Ritchie \& Roser, 2020). According to the National Inventory of Dams (USA), hydroelectric dams are more often removed than dams that provide other functions, primarily due to relicensing requirements (Grabowski et al., 2018). Additionally, some facilities may be rendered obsolete when regional power grids can use more efficient electricity sources (Baish et al., 2002). For example, the Woolen Mills dam in Wisconsin was built in 1919 for hydroelectricity generation but fell out of use by the 1950s. After showing structural flaws, it was removed in 1988 at 38 times cheaper than the replacement cost (Baish et al., 2002). In France, two dams along the Sélune River were considered for removal in 2009. Opponents of removal argued that the dams provided green energy (27 GWh/year) to help meet France's renewable energy targets. In contrast, the proponents argued that the two dams provided merely $0.04 \%$ of France's total hydropower production and significantly less electricity than the nuclear power generation station nearby (Germaine \& Lespez, 2017). The dams were not removed.

These cases reflect two contrasting decisions on hydroelectric dam removal. However, each was contentious and had stakeholders that represented both sides of the debate. It is important to note that both cases above originate from developed countries where access to electricity is nearly universal. In countries where individuals have limited access to electricity in their homes and workplaces, hydropower dams may be integral to closing the electricity access gap and improving livelihoods. Therefore, in developing regions that rely significantly on hydroelectricity for their power supply, dam removal may have far-reaching negative consequences and may not be a feasible alternative to overcome the issue of ageing dams. Case studies that explicitly support this statement are, however, currently lacking.

\subsection{Culture, History, and Heritage}

Regional heritage and cultural history can be impacted by removing a dam in that particular region. Dams may still hold value to residents because of their longstanding history and ties to past industries even though they no longer serve their intended function. In New England, USA, dams are often associated with old mill sites (Lenhart, 2003), while in Sweden, many dams historically served industrial communities, mills, and factories (Lejon et al., 2009). These dams are considered essential aspects of the environment. In fact, many old mill sites in New England were revitalized to preserve their historical importance to the economy in the 19th century (Kotval \& Mullin, 2009).

The commemoration of a dam's history may be essential to maintain the dam location's historical and cultural integrity post-removal. The inclusion of museums, plaques, or commemorative statues may be used to honor the history of a since-removed dam. In New Hampshire, USA, the timber cribbed McGoldrick 
Dam built in the 1850s was removed on the Ashuelot River in 2001 for ecological restoration purposes (NHDES, 2017). The dam's original use was rendered obsolete. However, the dam retained historical value as it allowed the nearby town to expand from an agricultural village to a manufacturing town in the 1800s. The State Historical Societies and State Historic Preservation Offices were involved in taking photographs to create a historical inventory. Then, plaques and interpretive signs were installed to commemorate the dam and educate the public on the river's rich history (Goddard-Bowman, 2014). The effort to create a historical inventory that can be shared with the public can lessen the negative impacts of dam removal on cultural history and heritage.

Conversely, dam removal may turn previously impacted areas to their original state. In North America, many Indigenous communities have deep spiritual ties to their land, rivers, and the resources they support. Many dams have negatively impacted these resources and were installed with little regard for and input from Indigenous communities (Guarino, 2013). For example, when the Glen Canyon Dam was built in Arizona, USA, hundreds of archaeological sites important to the Navajo Nation were lost (Baish et al., 2002). Similarly, in New Brunswick, Canada, the decision to repair an ageing dam disappointed Kingsclear First Nation, whose land rights, fishing grounds, and spiritual connection to the river were all diminished when the dam was built (White, 2016). The Mactaquac dam was estimated to cost CAD $\$ 3.6$ billion and CAD $\$ 4.3$ billion for repair and removal, respectively (White, 2016). Dam removal may allow the renewal of sacred land and increase the cultural and historical value in an area.

\subsection{Property Value}

A common fear of dam removal is the impact it will have on property value. Individuals living along reservoirs tend to believe that lakefront properties are more attractive to buyers in the real estate market than riverfront properties (Born et al., 1998; Bohlen \& Lewis, 2009; Nicholls \& Crompton, 2017). However, reports indicate that the river frontage is as much if not more valuable than the original lake frontage (Haberman, 1995). After the removal of a small dam in Wisconsin, USA, there was no significant change in property value when the residence was on the shore of the impoundment than along the free-flowing river. Additionally, housing value in the vicinity of the free-flowing river was higher than properties in the vicinity of the impoundment (Provencher et al., 2008). However, this study looked only at small dams where recreational value was limited. In Maine, USA, the removal of a large dam increased local property value, in part because of dam removal itself, but also due to improving water quality after dam removal (Lewis et al., 2008). Overall, the literature suggests that property values are unlikely to drop and may even improve when dams are removed, and rivers can flow naturally.

\subsection{Recreation}

Over 4000 dams globally registered in the ICOLD database serve recreational 
purposes (ICOLD WRD, 2020). Dam reservoirs may be used for watersports, fishing, swimming, camping, and hunting. Recreation is not a strictly decisive factor in dam building or removal of a dam; however, recreation often becomes an important secondary factor (Pohl, 2002). In addition, recreation attached to a dam is significantly weighted by the public as leisure activities (Wyrick et al., 2009). Therefore, dam removal is two-fold in recreational activities that can account for either gains or losses.

The recreational value of dams is challenging to quantify, as is after removal. Born et al. (1998) examined 30 small dams in Wisconsin, USA, and the public's opinion on their removal. They found that the main perceived deterrent of dam removal was the loss of recreation. However, those who supported dam removal cited an increase in recreation as one of their main arguments (Born et al., 1998). In addition, in the Pacific Northwest of the USA, removing four dams along the Snake River was projected to increase the river's recreational value by six to ten times (Loomis, 2002). Dam removal will eliminate the reservoir, which may decrease opportunities for watersports, boating, and swimming, but conversely, it may also improve recreational opportunities. After a dam is removed and the natural shoreline begins to re-establish, other recreational opportunities could be created, including whitewater rafting, canoeing, and kayaking (Loomis \& Walsh, 1997). Boat launches, recreational trails, and greenspace are also essential to facilitate recreation after dam removal. Given this dichotomy, it is vital to work with community members to optimize recreational uses after dam removal, and by implementing innovative alternatives, the loss of recreation from dam removal can be rectified.

\subsection{Aesthetics}

When considering dam removal, engineers and policymakers prioritize safety and economics while residents tend to prioritize aesthetics and recreation (Wyrick et al., 2009). As an essential group in the stakeholders of dam removal projects, considerations of community's perspectives are crucial to mitigate the potential loss of aesthetics after dam removal. In 2009, 17 dams in Sweden were in consideration for removal (Lejon et al., 2009). For stakeholders, aesthetic reasons against dam removal included muddy stream banks, loss of reflection ponds, and changing views. Proponents of dam removal stated the aesthetic value of free-flowing water (Jørgensen \& Renöfält, 2013). Aesthetics is an exceptionally subjective and polarizing topic. The preference for still or running water is the central anchoring point for both sides of the dam removal controversy (Jørgensen \& Renöfält, 2013). Likewise, one of a misconception that prevails is that dam removal will damage the scenery by resulting muddy, waterlogged, and unpleasant reservoir footprint (Sarakinos \& Johnson, 2003). While this may be true initially, studies post-removal indicate that vegetation grows back rapidly, and bare sediment is rare as soon as one year after removal (Lejon et al., 2009). Additionally, the nutrient-rich sediment and access to sunlight may improve growing conditions (Hörnström, 2009). In many cases, dam removal enhances aesthetics 
by increasing wildlife and water quality. Creating green space and riverfront revitalization during or after the removal processes can improve aesthetics and appease residents and users (Baish et al., 2002).

\subsection{Disaster Avoidance}

Even when structurally sound, large dams are considered "high hazard" forms of infrastructure because of the possible loss of human life resulting from failure (USBR, 2015). Urban development downstream of dams is persistent and thus elevates the magnitude of dam failure. Dam failures may result from seepage, cracking, overtopping or structural failure. Several failures have occurred in dams over 50 years old (Foster et al., 2000; Zhang et al., 2009). When combined with poor maintenance and infrequent inspection, older dams present a high risk to public safety. Dam failure can lead to extensive loss of life and property damage. For example, 1 billion USD in property losses were estimated as a result of the Teton Dam collapse in Idaho, USA. A small dam failure in West Virginia, USA, took the lives of 125 individuals (Ellingwood et al., 1993). Removing ageing dams that are vulnerable to failure is an effective and proactive way to prevent loss of life and to protect property.

\subsection{Socio-Economic Impacts of Dam Removal in Different Settings}

The extent of the impacts of dam removal may vary based on geographic location and socio-economic conditions. In developed nations where water availability is high, many ageing dams have been rendered obsolete. In these cases, removal may be the ideal choice to manage ageing infrastructure because of the cost-benefit and positive ecological impacts of regaining a free-flowing river. In countries such as the USA and Sweden, the primary concern for residents when considering dam removal is a loss of recreation, aesthetics, and property value. These impacts can largely be mitigated through education, commemoration, and the creation of greenspace surrounding the reservoir. In fact, these variables may increase after dam removal because of improved water quality and ecosystem health. However, dams are critical infrastructure for low-income countries for water supply, irrigation, and electricity generation. In these cases, dam removal may be impractical and not a viable option. Thus, implementing one-size-fits-all criteria to assess and prioritize dam removal projects in the global context is at least useless, and may be dangerous. Setting dam removal in the correct social, economic, and geographic context is critical to ensure sustainable development.

Climate projections estimate that global mean temperature will increase if greenhouse gas emissions continue at their current rate (Collins et al., 2013). However, the increase in temperature will not be uniform (Collins et al., 2013) nor will it impact all regions equally (Mendelsohn et al., 2006). Developing nations and those located in the global south are likely to suffer the most from a warming climate (Mendelsohn et al., 2006). Additionally, global water use has increased six-fold in the past century (Wada et al., 2016). As the climate becomes hotter 
and drier, increased pressure will be placed on governments and community leaders to supply water to growing populations. The global population is expected to increase to between 9.4 and 10 billion by 2050, with most of the growth occurring in Africa and Asia (UN Water, 2019). Therefore, innovative technologies and collaborative efforts will be required to provide safe, sufficient water to regions that are particularly vulnerable to climate change.

For the successful management of ageing dams, the dam removal process should be incorporated as a critical component in a dam's planning phase. The process should include all stakeholders who are positively and negatively impacted by an existing dam and consist of up-and-down-stream communities, engineers, dam managers, and policymakers. Additional considerations should consist of steps to rectify dam removal impacts, replace the existing benefits of a dam, and synchronize the environment and the communities with the dam removal. These should be considered critical in developing a framework for dam removal. Furthermore, scenario analysis for the risk and costs involved in a dam removal process should be required. Among others, Baecher et al., 1980; Boardman et al., 1996; Whitelaw \& Macmullan, 2002; Headwaters Economics, 2016; have discussed various concepts and methodologies of cost-benefit analysis for dam-removal based on case studies of various dam removal projects.

\section{Conclusion}

Dams have traditionally been used to secure water and electricity needs and provide a wealth of benefits, including irrigation, water supply, flood control, and recreation. However, thousands of large dams built in the middle of the previous century have already or will exceed their intended lifespan. As a result, their structural integrity or functional ability may become sub-optimal, and they will incur more significant maintenance costs while posing threats to the environment and human safety. Such issues lead to questions of dam repair, removal, or re-operationalization. Dam removal is a relatively recent phenomenon and has become common in the USA and Europe. Socio-economically, dam removal impacts aesthetic, recreational, historical, and property values and affects jobs and livelihoods. Developing and developed countries perceive dam removal in different contexts due to their technical and economic strengths. Therefore, it is unlikely to define unique combinations of socio-economic benefits in developing and developed worlds. Decisions regarding dam removal should incorporate social, economic, and geographic considerations in regionally explicit contexts. Overall, dam removal should be seen as equally important as dam building in the overall planning process on water storage infrastructure developments.

\section{Acknowledgements}

This research is supported by the funds received by UNU-INWEH through the long-term agreement with Global Affairs Canada. The year 2021 marks the 25-th anniversary of UNU-INWEH. Thanks are due to Dr. Vladimir Smakhtin (UNU- 
INWEH) for the constructive comments on the paper.

\section{Conflicts of Interest}

The authors declare no conflicts of interest regarding the publication of this paper.

\section{References}

Adams, A. (2000). Social Impacts of an African Dam: Equity and Distributional Issues in the Senegal River Valley. Contributing Paper, Thematic Review I. 1: Social Impacts of Large Dams Equity and Distributional Issues. https://ideas.repec.org/p/ess/wpaper/id514.html

Allen, M. B., Engle, R. O., Zendt, J. S., Shrier, F. C., Wilson, J. T., \& Connolly, P. J. (2016). Salmon and Steelhead in the White Salmon River after the Semoval of Condit Dam-Planning Efforts and Recolonization Results. Fisheries, 41, 190-203.

https://doi.org/10.1080/03632415.2016.1150839

Associated Press (2018). Dam Burst Inundates Villages, Veaves at Least Ten Dead. CBS News.

https://www.cbsnews.com/news/dam-burst-afghanistan-panjshir-valley-villages-floode d-homes-destroyed-deaths/

Baecher, G., Paté, M., \& de Neufville, R. (1980). Risk of Dam Failure in Benefit-Cost Analysis. Water Resources Research, 16, 449-456.

https://doi.org/10.1029/WR016i003p00449

Baish, S. K., David, S. D., \& Graf, W. L. (2002). The Complex Decision-Making Process for Removing Dams. Environment: Science and Policy for Sustainable Development, 44, 20-31. https://doi.org/10.1080/00139150209605779

Barker, R. (2004). Evolution of Irrigation in South and Southeast Asia. In Comprehensive Assessment of Water Management in Agriculture Series (Vol. 5).

https://books.google.ca/books?hl=en\&lr=\&id=U7vdUwCe4osC\&oi=fnd\&pg=PR5\&dq= dams+and+irrigation+in+asia\&ots=hPXPZcwwCB\&sig=yllvhjKBstoBOImv7TW_Zue UREs\#v=onepage \&q=dams $\% 20 \& \mathrm{f}=$ false

Bednarek, A. T., \& Hart, D. D. (2005). Modifying Dam Operations to Restore Rivers: Ecological Responses to Tennessee River Dam Mitigation. Ecological Applications, 15, 997-1008. https://doi.org/10.1890/04-0586

Bellmore, J. R., Duda, J. J., Craig, L. S., Greene, S. L., Torgersen, C. E., Collins, M. J., \& Vittum, K. (2017). Status and Trends of Dam Removal Research in the United States. WIREs Water, 4, e1164. https://doi.org/10.1002/wat2.1164

Berga, L. (2009). Dams and Floods. In: Y. Takahasi (Ed.), Water Storage, Transport and Distribution (pp 207-224). Paris, UNESCO-IHE and EOLSS Publishers Co. Ltd.

Boardman, A. E., Greenberg, D. H., Vining, A. R., \& Weimer, D. L. (1996). Cost-Benefit Analysis: Concepts and Practice. Prentice Hall.

Bohlen, C., \& Lewis, L. Y. (2009). Examining the Economic Impacts of Hydropower Dams on Property Values using GIS. Journal of Environmental Management, 90, 258-S269. https://doi.org/10.1016/j.jenvman.2008.07.026

Born, S. M., Genskow, K. D., Filbert, T. L., Hernandez-Mora, N., Keefer, M. L., \& White, K. A. (1998). Socioeconomic and Institutional Dimensions of Dam Removals: The Wisconsin Experience. Environmental Management, 22, 359-370.

https://doi.org/10.1007/s002679900111

Collins, M., Knutti, R., Arblaster, J., Dufresne, J.-L., Fichefet, T., Friedlingstein, P., Gao, 
X. et al. (2013). Long-Term Climate Change: Projections, Commitments and Irreversibility. In T. F. Stocker, D. Qin, G.-K. Plattner, M. Tignor, S. K. Allen, J. Boschung, A. Nauels, Y. Xia, V. Bex, \& P. M. Midgley (Eds.), Climate Change 2013: The Physical Science Basis. Contribution of Working Group I to the Fifth Assessment Report of the Intergovernmental Panel on Climate Change. Cambridge University Press. https://www.ipcc.ch/site/assets/uploads/2018/02/WG1AR5_Chapter12_FINAL.pdf

Cooper, B., \& Gleeson, J. (2012). Dams Safety Committee Annual Report 2011/2012. Dams Safety Committee.

https://www.parliament.nsw.gov.au/tp/files/57787/Dams\%20Safety\%20Committee\%20 Annual\%20Report\%202011-2012.pdf

Doyle, M. W., Harbor, J. M., \& Stanley, E. H. (2003). Toward Policies and Decision-Making for Dam Removal. Environmental Management, 31, 453-465. https://doi.org/10.1007/s00267-002-2819-Z

Duflo, E., \& Pande, R. (2007). Dams. The Quarterly Journal of Economics, 122, 601-646. https://doi.org/10.1162/qjec.122.2.601

Ellingwood, B., Corotis, R. B., Boland, J., \& Jones, N. P. (1993). Assessing Cost of Dam Failure. Journal of Water Resources Planning and Management, 119, 64-82. https://doi.org/10.1061/(ASCE)0733-9496(1993)119:1(64)

FEMA (1999). National Dam Safety Program. Federal Emergency Management Agency.

Fernando, C. H. (1980). Tropical Man-Made Lakes. African Fish and Cheap Protein. ICLARM Newsletter, 3, 15-18.

Ferre, L. E., McCormick, B., \& Thomas, D. S. K. (2014). Potential for Use of Social Vulnerability Assessments to Aid Decision Making for the Colorado Dam Safety Branch. Dam Safety, 2, 664-684.

Foster, M., Fell, R., \& Spannagle, M. (2000). The Statistics of Embankment Dam Failures and Accidents. Canadian Geotechnical Journal, 37, 1000-1024.

https://doi.org/10.1139/t00-030

Germaine, M. A., \& Lespez, L. (2017). The Failure of the Largest Project to Dismantle Hydroelectric Dams in Europe? (Sélune River, France, 2009-2017). Water Alternatives, 10, 655-676. http://www.water-alternatives.org/

Goddard-Bowman, R. (2014). Something Old Is Something New: The Role of Heritage Preservation in Economic Development. Papers in Canadian Economic Development, 9, 96-109. https://doi.org/10.15353/pced.v9i0.23

Grabowski, Z. J., Chang, H., \& Granek, E. F. (2018). Fracturing Dams, Fractured Data: Empirical Trends and Characteristics of Existing and Removed Dams in the United States. River Research and Applications, 34, 526-537. https://doi.org/10.1002/rra.3283

Grant, G. (2001). Dam Removal: Panacea or Pandora or Rivers? Hydrological Processes, 15, 1531-1532. https://doi.org/10.1002/hyp.473

Grant, G. E., \& Lewis, S. L. (2015). The Remains of the Dam: What Have We Learned from 15 Years of US Dam Removals? Engineering Geology for Society and Territory, 3, 31-35. https://doi.org/10.1007/978-3-319-09054-2_7

Grigg, N. S. (2019). Global Water Infrastructure: State of the Art Review. International Journal of Water Resources Development, 35, 181-205. https://doi.org/10.1080/07900627.2017.1401919

Guarino, J. (2013). Tribal Advocacy and the Art of Dam Removal: The Lower Elwha Klallam and the Elwha Dams. The American Indian Law Journal, 2, 114-145. https://www.researchgate.net/publication/292147269_TRIBAL_ADVOCACY_AND_T HE_ART_OF_DAM_REMOVAL_THE_LOWER_ELWHA_KLALLAM_AND_THE_E 
LWHA_DAMS/link/56aa7f2408aeadd1bdcad0aa/download

Haberman R. (1995). Dam Fights of the1990's: Removals. River Voices, 5, 1-6. https://www.rivernetwork.org/resource/river-voices-volume-5-number-4-1995-dam-fi ghts-1990s-removals/

Hanasaki, N., Kanae, S., \& Oki, T. (2006). A Reservoir Operation Scheme for Global River Routing Models. Journal of Hydrology, 327, 22-41. https://doi.org/10.1016/j.jhydrol.2005.11.011

Hardiman, J. M., \& Allen, M. B. (2015). Salmon Habitat Assessment for Conservation Planning in the Lower White Salmon River, Washington. US Department of the Interior, US Geological Survey Open-File Report 2015-1100, 24 p. https://doi.org/10.3133/ofr20151100

Hasnip, N., Mandal, S., Morrison, J., Pradhan, P., \& Smith, L. (2001). Contribution of Irrigation to Sustaining Rural Livelihoods. Report OD/TN109, HR Wallingford.

Headwaters Economics (2016). Dam Removal: Case Studies on the Fiscal, Economic, Social, and Environmental Benefits of Dam Removal.

http://headwaterseconomics.org/economic-development/local-studies/dam-removal-ca se-studies

Ho, M., Lall, U., Allaire, M., Devineni, N., Kwon, H. H., Pal, I., Raff, D., \& Wegner, D. (2017). The Future Role of Dams in the United States of America. Water Resources Research, 53, 982-998. https://doi.org/10.1002/2016WR019905

Hörnström, E. (2009). Plant Recoloinization Following Dam Removal: A Phytometer Experiment. Thesis, Umea University.

ICOLD WRD (International Commission on Large Dams World Register of Dams) (2020). World Register of Dams: General Synthesis.

https://www.icold-cigb.org/GB/world_register/general_synthesis.asp

IHA (2020). Hydropower Status Report: Sector Trends and Insights. International Hydropower Association. https://www.hydropower.org/status-report

Jackson, D. C., \& Marmulla, G. (2001). The Influence of Dams on River Fisheries. FAO Fisheries Technical Paper, 419, 1-44.

https://www.fao.org/3/y2785e/y2785e02.htm

Jayathilaka, S., \& Munasinghe, A. (2014). Dam Safety to Ensure the Public Safety. Dam Safety and Water Resources Planning Bulletin, Colombo, Sri Lanka. https://www.damsafety.lk/

Jørgensen, D., \& Renöfalt, B. M. (2013). Damned If You Do, Damned If You Don't: Debates on Dam Removal in the Swedish Media. Ecology and Society, 18, 18.

https://www.jstor.org/stable/26269265

https://doi.org/10.5751/ES-05364-180118

Kent, G. (1997). Fisheries, Food Security, and the Poor. Food Policy, 22, 393-404. https://doi.org/10.1016/S0306-9192(97)00030-4

Kotval, Z., \& Mullin, J. (2009). The Revitalization of New England's Small Town Mills: Breathing New Life into Old Places. Local Economy, 24, 151-167. https://doi.org/10.1080/02690940902717121

Labadie, J. W. (2004). Optimal Operation of Multi-reservoir Systems: State-of-the-Art Review. Journal of Water Resources Planning and Management, 130, 93-111. https://doi.org/10.1061/(ASCE)0733-9496(2004)130:2(93)

Lejon, A. G. C., Renofalt, B. M., \& Nilsson, C. (2009). Conflicts Associated with Aam Removal in Sweden. Ecology and Society, 14, 4.

https://www.jstor.org/stable/26268322 
https://doi.org/10.5751/ES-02931-140204

Lenhart, C. F. (2003). An Assessment of NOAA Community-based Fish Passage and Dam Removal Projects. Coastal Management, 31, 79-98. https://doi.org/10.1080/08920750390168318

Lewis, L. Y., Bohlen, C., \& Wilson, S. (2008). Dams, Dam Removal, and River Restoration: A Hedonic Property Value Analysis. Contemporary Economic Policy, 26, 175-186. https://doi.org/10.1111/j.1465-7287.2008.00100.x

Lipton, M., \& Litchfield, J. (2003). The Impact of Irrigation on Poverty. University of Sussex.

https://www.researchgate.net/publication/242185179_THE_IMPACT_OF_IRRIGATI ON_ON_POVERTY

Loomis, J. (2002). Quantifying Recreation Use Values from Removing Dams and Restoring Free-Flowing rivers: A Contingent Behavior Travel Cost Demand Model for the Lower Snake River. Water Resources Research, 38, 21-28. https://doi.org/10.1029/2000WR000136

Loomis, J. B., \& Walsh R. G. (1997). Recreation Economic Decisions; Comparing Benefits and Costs (No. Ed. 2). Venture Publishing Inc.

Mahmood, K. (1987). Reservoir Sedimentation: Impact, Extent, and Mitigation. The World Bank.

https://documents.worldbank.org/en/publication/documents-reports/documentdetail/ $\underline{888541468762328736 / \text { reservoir-sedimentation-impact-extent-and-mitigation }}$

Mapes, L. V. (2016). Elwha: Roaring Back to Life. The Seattle Times. http://projects.seattletimes.com/2016/elwha/

Mendelsohn, R., Dinar, A., \& Williams, L. (2006). The Distributional Impact of Climate Change on Rich and Poor Countries. Environment and Development Economics, 11, 159-178. https://doi.org/10.1017/S1355770X05002755

NHDES (New Hampshire Department of Environmental Services) (2017). McGoldrick Dam Removal Project, Ashuelot River, Hinsdale NH. Dam Removal and River Restoration Program.

https://www.swrpc.org/wp-content/uploads/2021/02/ASHLAC-PLAN-2006-Update.pd $\underline{f}$

Nicholls, S., \& Crompton, J. L. (2017). The Effect of Rivers, Streams, and Canals on Property Values. River Research and Applications, 33 1377-1386. https://doi.org/10.1002/rra.3197

Notzke, C. (1994). Aboriginal Peoples and Natural Resources in Canada. Captus Press. https://books.google.ca/books?hl=en\&lr=\&id=6VbIJTDlZIoC\&oi=fnd\&pg=PR9\&dq=d ams+in+canada+and+indigenous+pepople\&ots=fzGYPQLJKG\&sig=E0ODArqB2za6b 21JoZQVq3Xe7H0\#v=onepage \&q=dam\&f=false

Ohno, T. (2019). Contextual Factors Affecting the Modes of Interaction in Governance: The Case of Dam Removal in Japan. In K. Otsuka (Ed.), Interactive Approaches to Water Governance in Asia (pp. 55-76). Springer.

https://doi.org/10.1007/978-981-13-2399-7_3

Perera, D., Smakhtin, V., Williams, S., North, T., \& Curry, A. (2021). Ageing Water Storage Infrastructure: An Emerging Global Risk. UNU-INWEH Report Series, Issue 11. United Nations University Institute for Water, Environment and Health, Hamilton, Canada.

https://inweh.unu.edu/wp-content/uploads/2021/01/Ageing-Water-Storage-Infrastruct ure-An-Emerging-Global-Risk_web-version.pdf

Pohl, M. M. (2002). Bringing Down Our Dams: Trends in American Dam Removal Ra- 
tionales. Journal of the American Water Resources Association, 38, 1511-1519.

https://onlinelibrary.wiley.com/doi/pdf/10.1111/j.1752-1688.2002.tb04361.x?casa_toke n=zUcQsLbelQcAAAAA:K2WRfcj88gCDpF0Y4vx3XETkxc_uwjrmnRxvWTxPUT0Ou YSZYxoUcZbctTjp-AJWwA1WmiyJ9Hjbkq0s https://doi.org/10.1111/j.1752-1688.2002.tb04361.x

Provencher, B., Sarakinos, H., \& Meyer, T. (2008). Does Small Dam Removal Affect Local Property Values? An Empirical Analysis. Contemporary Economic Policy, 26, 187-197. https://doi.org/10.1111/j.1465-7287.2008.00107.x

Ritchie, H., \& Roser, M. (2020). Access to Energy. Our World in Data. https://ourworldindata.org/energy-access

Sarakinos, H., \& Johnson, S. E. (2003). Social Perspectives on Dam Removal. In Dam Removal Research: Status and Prospects. The H. John Heinz III Center for Science, Economics and the Environment.

Schultz, B. (2002). Role of Dams in Irrigation, Drainage and Flood Control. International Journal of Water Resources Development, 18, 147-162. https://doi.org/10.1080/07900620220121710

Shah, Z., \& Kumar, M. D. (2008). In the Midst of the Large Dam Controversy: Objectives, Criteria for Assessing Large Water Storages in the Developing World. Water Resources Management, 22, 1799-1824. https://doi.org/10.1007/s11269-008-9254-8

Sugunan, V. V. (1995). Reservoir Fisheries of India. Food and Agriculture Organization of the United Nations.

https://books.google.ca/books?hl=en\&lr=\&id=gWxskWs5WywC\&oi=fnd\&pg=PA1\&d $\mathrm{q}=$ dams+and+reservoir+fisheries\&ots=ku-lob37TU\&sig=XXbr98XQ9oHvmsKQVGR TmlRNC0k\&redir_esc $=\mathrm{y} \# \mathrm{v}=$ snippet $\& \mathrm{q}=\mathrm{dam} \& \mathrm{f}=$ false

UN Water (2019). Leaving No One Behind. World Water Development Report. https://www.unwater.org/publications/world-water-development-report-2019/

USBR (2015). Dam Failure and Flood Event Case History Compilation. RECM-Reclamation Consequence Estimating Methodology.

https://www.usbr.gov/ssle/damsafety/documents/RCEM-CaseHistories2015.pdf

Vonk, E., Xu, Y. P., Booij, M. J., Zhang, X., \& Augustijin, D. C. M. (2014). Adapting Multireservoir Operation to Shifting Patterns of Water Supply and Demand. Water Resources Management, 28, 625-643. https://doi.org/10.1007/s11269-013-0499-5

Vörösmarty, C. J., McIntyre, P., Gessner, M., Dudgeon, D., Prusevich, P., Green, S., Glidden, S., Bunn, S. E., Sullivan, C. A., Reidy, L. C., \& Davies, P. M. (2010). Global Threats to Human Water Security and River Biodiversity. Nature, 467, 555-561.

https://doi.org/10.1038/nature09440

Wada, Y., Flörke, M., Hanasaki, N., Eisner, S., Fischer, G., Tramberend, S. et al. (2016). Modelling Global Water Use for the 21st Century: The Water Futures and Solutions (WFaS) Initiative and Its Approaches. Geoscientific Model Development, 9, 175-222. https://doi.org/10.5194/gmd-9-175-2016

Watts, R. J., Richter, B. D., Opperman, J. J., \& Bowmer, K. H. (2011). Dam Reoperation in an Era of Climate Change. Marine and Freshwater Research, 62, 321-327. https://doi.org/10.1071/MF10047

White, A. (2016). “The Lake Stays”: NB Power Opts to Keep Mactaquac Dam until 2068. CBC News.

https://www.cbc.ca/news/canada/new-brunswick/mactaquac-nbpower-dam-future-opt ion-1.3905066

Whitelaw, E., \& Macmullan, E. (2002). A Framework for Estimating the Costs and Benefits of Dam Removal: Sound Cost-Benefit Analyses of Removing Dams Account for 
Subsidies and Externalities, for Both the Short and Long Run, and Place the Estimated Costs and Benefits in the Appropriate Economic Context. BioScience, 52, 724-730. https://doi.org/10.1641/0006-3568(2002)052[0724:AFFETC]2.0.CO;2

Witze, A. (2014). Dam Demolition Lets the Elwha River Run Free. Science News. https://www.sciencenews.org/article/dam-demolition-lets-elwha-river-run-free

WWAP (2017). Facts and Figures. United Nations Educational, Scientific and Cultural Organization.

http://www.unesco.org/new/en/natural-sciences/environment/water/wwap/facts-and-fi gures/all-facts-wwdr3/fact-6-hydropower/

Wyrick, J. R., Rischman, B. A., Burke, C. A., McGee, C., \& Williams, C. (2009). Using Hydraulic Modeling to Address Social Impacts of Small Dam Removals in Southern New Jersey. Journal of Environmental Management, 90, S270-S278.

https://doi.org/10.1016/j.jenvman.2008.07.027

Yang, M., Quian, X., Zhang, Y., Sheng, J., Shen, D., \& Ge, Y. (2011). Spatial Multicriteria Decision Analysis of Flood Risks in Aging-Dam Management in China: A Framework and Case Study. Journal of Environmental Research and Public Health, 8, 1367-1387. https://doi.org/10.3390/ijerph8051368

Zamarrón-Mieza, I., Yepes, V., \& Moreno-Jiménez, J. M. (2017). A Systematic Review of Application of Multi-Criteria Decision Analysis for Aging-Dam Management. Journal of Cleaner Production, 147, 217-230. https://doi.org/10.1016/j.jclepro.2017.01.092

Zhang, L. M., Xu, Y., \& Jia, J. S. (2009). Analysis of Earth Dam Failures: A Database Approach. Georisk: Assessment and Management of Risk for Engineered Systems and Geohazards, 3, 184-189. https://doi.org/10.1080/17499510902831759

Zimmermann, F. B. (2019). Brazil's Latest Dam Disaster: Human Loss and Environmental Degradation. Australian Outlook.

https://www.internationalaffairs.org.au/australianoutlook/brazil-dam-disaster/ 